\title{
A retrospective controlled study of tranquillizers in long-stay patients
}

\author{
A. A. ROBIN
}

From Runwell Hospital, Wickford, Essex

Controlled studies of tranquillizers, both phenothiazine and rauwolfia derivatives, show improvement in those patients staying for long periods in hospital in such symptoms as motor restlessness, psychomotor agitation and excitement (Vaughan, Leiberman, and Cook, 1955), tension, delusions, hostility, and sociability (Wing, 1956). Few authors discuss the outcome in terms of the patients' discharge but American epidemiological studies (Brill and Patton, 1957; 1959), which 'were not computed specific for patients on drugs' (Kramer and Pollack, 1958), have suggested that tranquillizers have had a marked effect on the discharge of such patients, and the number discharged from hospital in England and Wales has also increased from 2,451 in 1954 to 4,170 in 1958 (Brooke, 1962).

The following study examines the effect of tranquillizers on outcome, using controls, by a retrospective analysis of 276 matched pairs in each of which one patient was treated with tranquillizers.

\section{DESIGN OF THE STUDY}

The design employed is similar to that discussed in a study of the effects of leucotomy (Robin, 1958) and retains the object of creating a control group with the same outlook as the treatment group, the controls also being under treatment at the same time. In the case of the controls, this consisted essentially of nursing care, occupation, and occasional symptomatic sedation with barbiturates or paraldehyde. The tranquillized patients were treated with chlorpromazine (260 patients) reserpine (81), pecazine (44), prochlorperazine (36), acetyl promazine (22), promazine (10), perphenazine (8), trifluoperazine (4), triflupromazine (4), and thiopropazate (3). As far as dosage is concerned, 45 patients received more than $300 \mathrm{mg}$. chlorpromazine daily, the highest dose being $1,050 \mathrm{mg}$. daily; 125 received 75 to $100 \mathrm{mg}$. t.d.s., 55 received $50 \mathrm{mg}$. t.d.s., and 35 only $75 \mathrm{mg}$. daily. Twenty-nine patients received more than $3 \mathrm{mg}$. reserpine daily, 72 patients $3 \mathrm{mg}$., and 20 less than this quantity per day. The other drugs appear to have been prescribed, in general, as suggested by the manufacturers.

As in the last study, objective prognostic indicatorssex, age, length of stay in hospital before treatmentwere used, but in this study diagnosis was also matched.

Where precise matching, using the criteria below, proved impossible prognostic disadvantages, e.g., higher age, longer stay, were first allocated to the control group. The analysis of outcome proceeds to 31 December 1958, a relatively early date being chosen because of the progressive loss of untreated long-stay patients to the tranquillized group with the passage of time.

\section{METHOD}

A chronologically arranged index was prepared of all patients with a hospital residence exceeding two years under treatment between 1 January 1952 and 31 Decembet 1958.

Case records and treatment cards were examined to indicate patients who within these dates received trang 을

\section{TABLE Ia}

AGE IN 1952 OF 276 CASES AND MATCHED CONTROLS

\begin{tabular}{|c|c|c|c|c|}
\hline \multirow{2}{*}{$\begin{array}{l}\text { Age in } \\
1952 \\
(y r .)\end{array}$} & \multicolumn{2}{|l|}{ Males } & \multicolumn{2}{|l|}{ Females } \\
\hline & Drug-treated & Controls & Drug-treated & Controls \\
\hline-20 & 2 & - & 2 & - \\
\hline $21-30$ & 21 & 13 & 13 & 7 \\
\hline $31-40$ & 40 & 33 & 35 & 19 \\
\hline 41-50 & 25 & 41 & 35 & 45 \\
\hline $51-60$ & 15 & 15 & 35 & 47 \\
\hline $61-70$ & 7 & 7 & 27 & 26 \\
\hline 71- & 6 & 7 & 13 & 14 \\
\hline Totals & 116 & 116 & 160 & 160 \\
\hline
\end{tabular}

TABLE Ib

LENGTH OF STAY OF 276 CASES AND MATCHED CONTROLS

\begin{tabular}{lllll}
$\begin{array}{l}\text { Period from } \\
\begin{array}{l}\text { Admission to } \\
\text { Drug Date }\end{array}\end{array}$ & Males & Females \\
\cline { 5 - 6 } \cline { 4 - 5 } & Drug-treated & Controls & Drug-treated Controls \\
\hline
\end{tabular}

$-1 \mathrm{mth}$.

$-3 \mathrm{mth}$.

$-6 \mathrm{mth}$.

$-1 \mathrm{yr}$.

$-2 \mathrm{yr}$.

$-3 \mathrm{yr}$.

-4 yr.

-5 yr.

-10 yr.

$+10$

Totals

4

\begin{tabular}{l}
3 \\
3 \\
\hline
\end{tabular}

2
16

16
2

8

6

29
43

116 
TABLE IC

DIAGNOSIS IN 276 CASES AND MATCHED CONTROLS

\begin{tabular}{|c|c|c|c|c|}
\hline \multirow[t]{2}{*}{ Diagnosis } & \multicolumn{2}{|l|}{ Males } & \multicolumn{2}{|l|}{ Females } \\
\hline & $\begin{array}{l}\text { Drug- } \\
\text { treated }\end{array}$ & Controls & $\begin{array}{l}\text { Drug- } \\
\text { treated }\end{array}$ & Controls \\
\hline $\begin{array}{l}\text { Schizophrenic reaction } \\
\text { Paranoid reactions } \\
\text { Melancholia } \\
\text { Mania } \\
\text { Manic depres- } \\
\text { sive psychosis } \\
\text { Neurosis (psychopathic } \\
\text { personality) } \\
\text { Subnormality } \\
\text { Epilepsy } \\
\text { Organic disorders }\end{array}$ & $\left.\begin{array}{r}85 \\
4 \\
e \\
6 \\
1 \\
5\end{array}\right\} 12$ & $\left.\begin{array}{r}86 \\
4 \\
7 \\
3 \\
1\end{array}\right\} 11$ & $\left.\begin{array}{l}83 \\
18 \\
13 \\
9 \\
4\end{array}\right\} 26$ & $\left.\begin{array}{r}79 \\
24 \\
20 \\
5 \\
2\end{array}\right\} 27$ \\
\hline Totals & 116 & 116 & 160 & 160 \\
\hline
\end{tabular}

TABLE Id

ADMISSIONS IN 276 CASES AND MATCHED CONTROLS

\begin{tabular}{|c|c|c|c|c|}
\hline \multirow{2}{*}{$\begin{array}{l}\text { Number of Previous } \\
\text { Admissions }\end{array}$} & \multicolumn{2}{|l|}{ Males } & \multicolumn{2}{|c|}{ Females } \\
\hline & $\begin{array}{l}\text { Drug- } \\
\text { treated }\end{array}$ & Controls & $\begin{array}{l}\text { Drug- } \\
\text { treated }\end{array}$ & Controls \\
\hline One & 19 & 20 & 17 & 15 \\
\hline Two & 13 & 8 & 14 & 7 \\
\hline Three & 6 & 3 & 2 & 3 \\
\hline Four and over & 6 & 4 & 2 & 4 \\
\hline \multirow{2}{*}{$\begin{array}{l}\text { Number previously } \\
\text { admitted } \\
\text { Number not previously } \\
\text { admitted }\end{array}$} & 44 & 35 & 35 & 29 \\
\hline & 72 & 81 & 125 & 131 \\
\hline Totals & 116 & 116 & 160 & 160 \\
\hline
\end{tabular}

quillizers as listed above, and patients who received tranquillizers for less than a month (19 in all) were discarded as inadequately treated.

Each tranquillized patient was matched with the untreated patient of the same sex, age in 10-year blocks, and diagnosis nearest to him in the index, working backwards from the tranquillized patient's date of admission for three years, yet still in hospital when the tranquillized patient was treated.

Where matching was not possible in all criteria, sex was always held constant, age was first varied 10 years up and 10 years down, and finally diagnosis was varied within the functional (schizophrenia, paraphrenia, affective disorders, neurosis) and organic (dementia, confusional psychosis, chorea, epilepsy) groups, but not between them.

Twenty-two drug-treated cases, two treated for from one to three months and 20 for more than three months, could not be matched on this basis and these are considered separately. The results in 10 matched cases treated for from one to two months and 20 treated from two to three months are likewise shown separated from the largest group of 246 matched pairs where the treated patient received drugs for longer than three months (Table II).

Although the control group was slightly older and more chronically ill, Table I shows the closeness of matching. To facilitate the comparison of length of stay each control case was allocated the date on which its matched pair started treatment for use as a hypothetical drug date. These cases were not matched for the number of previous admission to Runwell Hospital, but it will be seen they are comparable in this respect also (Table Id).

TABLE II

OUTCOME IN 276 MATCHED PAIRS TREATED AND UNTREATED WITH TRANQUILLIZERS WITH RESULTS IN 22 FURTHER UNMATCHED TREATED CASES ${ }^{1}$

Period from Drug

Date to Discharge,

Death, or

Termination

Drug-treated

Never Dis- Dis-

charged charged
Control

\begin{tabular}{lllll}
\hline $\begin{array}{l}\text { Never Dis- } \\
\text { charged }\end{array}$ & $\begin{array}{l}\text { Dis- } \\
\text { charged }\end{array}$ & Dead & $\begin{array}{l}\text { Trans- } \\
\text { ferred }\end{array}$ & Total
\end{tabular}

charged charged

ferred

\begin{tabular}{ll}
\hline Males & \\
$<6$ mth. & $13(1)$ \\
$1 \mathrm{yr}$. & 13 \\
$2 \mathrm{yr}$. & $26(4)$ \\
$3 \mathrm{yr}$. & 23 \\
$4 \mathrm{yr}$. & $12(1)$ \\
$5 \mathrm{yr}$. & 7 \\
Totals & $94(6)$ \\
Unmatched cases & 11 \\
Totals & 105
\end{tabular}

$\begin{array}{ccr}- & 2(2) & 1 \\ 5(1) & - & - \\ 2 & 5 & - \\ 5(2) & - & - \\ 1(1) & - & - \\ -13(4) & -7(2) & 2 \\ 1 & - & - \\ 14 & 7 & 2\end{array}$

Trans-

Total

$\begin{array}{lc}\begin{array}{l}\text { Females } \\ <6 \mathrm{mth} .\end{array} & \\ 1 \mathrm{yr} . & 25(5) \\ 2 \mathrm{yr} . & 17(1) \\ 3 \mathrm{yr} . & 28(5) \\ 4 \mathrm{yr} . & 54(3) \\ 5 \mathrm{yr} . & 12(2) \\ \text { Totals } & - \\ \text { Unmatched cases } & 136(16) \\ \text { Totals } & 6 \\ & 142\end{array}$

2
$2(1)$
5
3
-
$\overline{12}$
4
16

$\begin{array}{ll}-5(1) & - \\ 3 & - \\ 4 & - \\ \overline{12} & - \\ 12 & -\end{array}$

$\begin{array}{rl}16 & 15(1) \\ 18 & 11 \\ 33 & 27(4) \\ 29 & 21(1) \\ 13 & 13 \\ 7 & 3 \\ 116 & 90(6) \\ 12 & - \\ 128 & 90\end{array}$

$4(1)$
$5(2)$
2
2
-
$\frac{13(3)}{13}$

1
$3(1)$
$3(1)$
$3(1)$
$\frac{1}{11(3)}$
$\frac{11}{11}$

$\begin{array}{lr}- & 20 \\ 1 & 20 \\ - & 33 \\ - & 26 \\ - & 13 \\ -2 & 116 \\ 2 & 116\end{array}$

'Cases treated for one to three months and their controls are shown in parentheses.

$\begin{array}{rccccc}27 & 27(5) & 6(1) & 3 & - & 36 \\ 24 & 14(1) & 3(1) & 2 & - & 19 \\ 36 & 28(6) & 1 & 8(1) & 1 & 38 \\ 61 & 48(1) & 2 & 2(1) & - & 52 \\ 12 & 15(1) & - & - & - & 15 \\ \overline{160} & \overline{132(14)} & \overline{12(2)} & \overline{15}(2) & - & -160 \\ 10 & - & \overline{12} & \overline{15} & - & -160\end{array}$




\section{RESULTS}

The close similarity of the results obviates the need for statistical tests of significance. Inspection of the overall results (Table II) shows equal numbers discharged after a similar period of treatment from both the tranquillized group and the control group, even when the former have added to them all successes from the unmatched cases. There is likewise no difference in death rates.

Examination of Table Ib will, however, show that two types of long-stay cases are being considered, namely, patients who remained in hospital for two years and then received tranquillizers ( 88 males and 135 females), and patients who were tranquillized before they achieved long stay status, but neverthe-

TABLE III

CASES DISCHARGED FROM DRUG-TREATED AND CONTROL GROUPS

$\begin{array}{llll}\text { Males } & \text { Controls } & \begin{array}{l}\text { Females } \\ \begin{array}{c}\text { Drug- } \\ \text { treated }\end{array}\end{array} \text { Controls }\end{array}$

Diagnosis

\begin{tabular}{lrrrr}
\hline Schizophrenia & 7 & 8 & 5 & 6 \\
Paranoid reaction & 0 & 1 & 1 & 2 \\
Affective reaction & 4 & 3 & 4 & 1 \\
Neuroses & 1 & 0 & 2 & 2 \\
Organic reactions & 1 & 1 & 0 & 1 \\
Totals & 13 & 13 & 12 & 12
\end{tabular}

Admission date-drug date

$<2$ years

$>2$ years

Total

9
4
13

Age (yr.)

-30
-40

-40
-50

$-60$

$60+$

Total
8

13

5
7
12

$\begin{array}{rr}5 & 4 \\ 2 & 2 \\ 2 & 5 \\ 3 & 2 \\ 1 & 0 \\ 13 & 13\end{array}$

less did so (28 males and 25 females). When the results in these categories are considered separately they too show no significant differences between treated and control groups.

Finally, when the patients discharged from drug and control groups are compared, they are shown (Table III) to be similar in the distribution of diagnosis, length of stay before treatment, age, and sex, while the stability of their discharge is also similar in that five drug-treated patients of 25 discharged were readmitted compared with four controls readmitted.

\section{SUMMARY}

Results in 276 long-stay patients treated with tranquillizers were compared with those in 276 controls, matched for chronicity, age, sex, diagnosis, and under treatment at the same time. Tranquillizers did not improve their chances of discharge from hospital, accelerate discharge, affect their chance of readmission, or affect the death rate. The patients discharged from treatment and control groups appeared similar in sex, age distribution, chronicity and diagnosis.

This work was made possible by grants from the Nuffiel Provincial Hospitals Trust and W. Warner Ltd., Eastleigh Hants. I wish to thank Dr. J. Dawson, Director of Re search, for critical advice.

\section{REFERENCES}

Brill, H., and Patton, R. E. (1957). Amer. J. Psychiat., 114, 509. - (1959). Ibid., 116, 495.

Brooke, E. (1962). Personal communication.

Kramer, M., and Pollack, E. S. (1958). Amer. J. publ. Hlth, 48, 1003.

Robin, A. A. (1958). J. Neurol. Neurosurg. Psychiat., 21, 262.

Vaughan, G. F., Leiberman, D. M., and Cook, L. C. (1955). Lancet, $1,1083$.

Wing, L. (1956). J. ment. Sci., 102, 530. 